\title{
PELAKSANAAN KKN KEMANUSIAAN MAHASISWI STIBA \\ MAKASSAR DI KELURAHAN MALUNDA, KABUPATEN MAJENE
}

\section{COMMUNITY SERVICE OF HUMANITY OF STIBA MAKASSAR IN MALUNDA VILLAGE, MAJENE REGENCY}

\section{Zulfiah Sam}

Sekolah Tinggi Ilmu Islam dan Bahasa Arab (STIBA) Makassar zulfiahsam@stiba.ac.id

\section{Saadal Jannah}

Sekolah Tinggi Ilmu Islam dan Bahasa Arab (STIBA) Makassar saadaljannah@stiba.ac.id

\section{Sartini Lambajo}

Sekolah Tinggi Ilmu Islam dan Bahasa Arab (STIBA) Makassar sartini@stiba.ac.id

\begin{tabular}{|c|c|}
\hline Keywords: & ABSTRACT \\
\hline $\begin{array}{l}\text { Disaster, Humanitiy, } \\
\text { Community Service, Malunda }\end{array}$ & $\begin{array}{l}\text { Kelurahan Malunda is one of the areas affected by an earthquake } \\
\text { measuring } 6.2 \text { on the Richter scale in West Sulawesi. Disaster } \\
\text { survivors who survive in refugee camps are very vulnerable to post- } \\
\text { disaster trauma, which is why the Humanitarian Community Service } \\
\text { Program of STIBA Makassar aims to carry out the three principles } \\
\text { of higher education by taking on the role of service and humanity in } \\
\text { the Malunda area. The method of implementing the program begins } \\
\text { by identifying the needs of the people in the affected areas using } \\
\text { SOAR analysis which then results in several programs including } \\
\text { social service, teaching the Koran with the dirosa method, Muslim } \\
\text { taklim, memorizing the Koran for teenagers and a religious child } \\
\text { festival. The results of the implementation of this program have had } \\
\text { quite a positive effect on the community in dealing with post- } \\
\text { earthquake psychological stress, as well as making a significant } \\
\text { contribution to the quality of volunteer personnel in helping affected } \\
\text { communities in the Malunda village. }\end{array}$ \\
\hline \multirow{2}{*}{$\begin{array}{l}\text { Kata kunci : } \\
\text { Bencana Alam, Kemanusiaan, } \\
\text { KKN, Malunda. }\end{array}$} & ABSTRAK \\
\hline & $\begin{array}{l}\text { Kelurahan Malunda merupakan salah satu wilayah yang terdampak } \\
\text { bencana gempa bumi berkekuatan } 6.2 \mathrm{SR} \text { di Sulawesi Barat. Para } \\
\text { penyintas bencana yang bertahan di tenda-tenda pengungsian sangat } \\
\text { rentan mengalami trauma pasca bencana, karena itulah KKN } \\
\text { kemanusiaan STIBA Makassar bertujuan untuk melaksanakan tri } \\
\text { darma perguruan tinggi dengan mengambil peran pengabdian dan } \\
\text { kemanusiaan di wilayah Malunda. Metode pelaksanaan program } \\
\text { diawali dengan mengidentifikasi kebutuhan masyarakat di wilayah } \\
\text { terdampak dengan menggunakan analisis SOAR yang kemudian } \\
\text { menghasilkan beberapa program di antaranya bakti sosial, }\end{array}$ \\
\hline
\end{tabular}


pengajaran Al-Qur'an metode dirosa, taklim muslimah, menghafal Al-Qur'an bagi remaja dan festival anak saleh. Hasil dari pelaksanaan program ini memberikan efek yang cukup positif bagi masyarakat dalam menangani tekanan psikologis pasca gempa, serta memberikan kontribusi yang signifikan bagi kualitas personil relawan dalam membantu masyarakat yang terdampak di kelurahan Malunda.

Diterima: 27 April 2021; Direvisi: 4 Mei 2021; Disetujui: 18 Mei 2021; Tersedia online: 18 Juni 2021

How to cite: Zulfiah Sam, Saadal Jannah, Sartini Lambajo, "Pelaksanaan KKN Kemanusiaan STIBA Makassar di Kelurahan Malunda, Kabupaten Majene", WAHATUL MUJTAMA': Jurnal Pengabdian Masyarakat Vol, No (Juni, 18, 2021): 1-10. doi: https://doi.org/10.36701/wahatul.v2i1.339

\section{PENDAHULUAN}

Hari Jumat 15 Januari 2021 merupakan hari yang mungkin tidak dapat dilupakan masyarakat di wilayah Sulawesi Barat, gempa bumi dengan kekuatan 6,2 SR mengguncang dan meluluhlantakkan bangunan dan tempat tinggal warga serta menyebabkan longsor. Gempa yang terjadi di pagi buta sekitar pukul 02.28 WITA dengan titik episentrum $2.98^{\circ} \mathrm{S} 118.94^{\circ} \mathrm{E}, 10 \mathrm{~km}$ Timur Laut Majene Sulawesi Barat tidak berpotensi tsunami, namun menyebabkan ratusan korban jiwa dan puluhan rumah ambruk dan rusak. Akibatnya para korban selamat yang berada ditendatenda pengungsian mengalami kepanikan, kecemasan dan trauma disamping juga sangat membutuhkan bantuan logistik, obat-obatan dan tempat mengungsi yang memadai.

Wilayah yang terdampak cukup parah adalah Kabupaten Majene dan Kabupaten Mamuju. Berdasarkan data Basarnas Mamuju, korban jiwa di Kabupaten Majene 10 orang dan di Kabupaten Mamuju 95 orang sehingga total korban jiwa mencapai 105 orang. Sementara jumlah korban luka-luka akibat gempa di dua wilayah tersebut sebanyak 3.369 orang, dan yang terpaksa harus mengungsi sejumlah 89.524 orang. Kerugian materiel di Kabupaten Majene berupa satu kantor Danramil rusak, 17 fasilitas kesehatan, 4.122 rumah, dan sebanyak 32 fasilitas ekonomi dan perkantoran rusak, sementara di Kabupaten Mamuju, sebanyak 3.741 rumah rusak, kantor gubernur, 5 unit fasilitas kesehatan, 3 jembatan rusak dan satu pelabuhan ${ }^{1}$.

Kondisi pasca gempa yang masih diiringi dengan gempa-gempa susulan membuat masyarakat terpaksa harus bertahan di tenda-tenda pengungsian, hal tersebut tentu diwarnai dengan kondisi pengungsian yang belum memadai, angin dan hujan yang mengguyur membawa masalah kesehatan lain bagi sebagian

\footnotetext{
${ }^{1}$ Profil Kelurahan Malunda.
} 
pengungsi, kekhawatiran masyarakat juga tidak hanya terkait gempa akan tetapi kewaspadaan terhadap pencurian bagi rumah-rumah yang ditinggalkan selama mengungsi, oknum-oknum yang tidak bertanggung jawab memanfaatkan situasi ini untuk menggasak harta benda yang ditinggal penghuninya. Rangkaian masalah yang timbul tersebut tentu sangat berdampak bagi psikologis para pengungsi di samping trauma yang juga mendalam dirasakan khususnya wanita dan anak-anak, hal tersebut membutuhkan pemulihan atau yang dikenal dengan istilah trauma healing pasca bencana. Sehubungan dengannya, berdasarkan PkM yang dilakukan oleh Setiawan, dkk, menunjukkan bahwa pasca pendampingan trauma pascagempa, semua penyintas dinyatakan sembuh dari traumanya ${ }^{2}$.

Pembinaan keagamaan dapat dikategorikan sebagai salah satu bentuk trauma healing yang dibutuhkan oleh para penyintas bencana, walaupun pemenuhan kebutuhan sandang, pangan dan papan juga dapat membantu menenangkan kejiwaan namun hal yang tidak kalah pentingnya adalah kondisi psikologis yang stabil dalam menerima kenyataan kehilangan yang dialami, karena sejatinya hal buruk yang menimpa tidak bisa dilupakan oleh manusia akan tetapi bagaimana mengatasi rasa takut, panik dan gelisah bisa menjadi ketenangan dan kedamaian, rasa putus asa dan hampa beralih menjadi rasa optimis dan harapan akan kehidupan yang lebih baik di masa mendatang.

Dalam usaha mengatasi kondisi para pengungsi pasca bencana di wilayah Sulawesi Barat tersebut, maka STIBA Makassar mengutus beberapa mahasiswi KKN untuk memberikan pembinaan keagamaan. Berdasarkan kondisi yang dipaparkan di atas maka dapat diuraikann beberapa hal yang menjadi tujuan pelaksanaan KKN sebagai berikut:

1. Mengambil peran dalam membantu program pemerintah dalam proyek kemanusiaan dalam hal ini mengatasi permasalahan yang timbul pasca bencana.

2. Merupakan sarana meningkatkan kepekaan sosial dan kemanusiaan serta dakwah para mahasiswa STIBA Makassar sebagai wujud nyata kontribusi pengabdian kepada masyarakat.

3. Sebagai perguruan tinggi keagamaan Islam maka STIBA Makassar berkewajiban melaksanakan tri dharma perguruan tinggi khususnya pengabdian kepada masyarakat.

Berdasarkan kondisi pasca bencana yang terjadi di wilayah Sulawesi Barat khususnya di Kelurahan Malunda Kabupaten Majene, maka dibutuhkan survei

${ }^{2}$ Setiawan, Heri, et al. "Pendampingan Trauma Pascagempa Berbasis Kearifan Lokal di Desa Kayangan Kabupaten Lombok Utara." Jurnal Abdimas PHB: Jurnal Pengabdian Masyarakat Progresif Humanis Brainstorming 4.1 (2021): 115. 
lapangan dalam menganalisis program pembinaan keagamaan yang dibutuhkan dengan menggunakan instrumen analisis SOAR sebagai berikut:

1. Strenght, antusias masyarakat dalam memperbaiki kualitas keimanannya melalui pembinaan keagamaan. Jumlah muslimah yang banyak dari kalangan ibu-ibu, remaja dan anak. Selain itu, mahasiswi KKN STIBA telah dibekali dengan beberapa pelatihan pembinaan keagamaan seperti, pengajaran AlQur'an untuk dewasa dan anak-anak, pengajaran bahasa Arab, public speaking dan lain-lain.

2. Opportunitis, adanya program pemerintah yang sejalan yaitu pemberantasan buta baca Al-Qur'an dan peningkatan kualitas keberagamaan masyarakat. Antusias masyarakat yang sangat besar dan dukungan pemerintah setempat, serta keberadaan lembaga dakwah di Kelurahan Malunda.

3. Aspiration, masyakarat membutuhkan pembinaan dasar-dasar keislaman yang berkelanjutan. Pembinaan baca dan tadabur Al-Qur'an dengan lebih intensif baik untuk orang dewasa maupun anak-anak.

4. Result, terwujudnya masyarakat berakidah kuat dan berakhlak Islam, serta terbentuknya generasi qurani yang tangguh.

Berangkat dari analisis singkat di atas, maka ditetapkan beberapa program kerja KKN mahasiswi STIBA Makassar di Kelurahan Malunda berupa bakti sosial, pengajaran Al-Qur'an orang dewasa dan anak-anak, taklim fikih muslimah, daurah Ramadan muslimah, pengajaran bahasa Arab untuk anak-anak, taklim remaja, tahfiz Al-Qur'an, dan festival anak saleh Desa Lombang.

Sejumlah aksi PkM terdahulu dan relevan dengan pelaksanaan KKN kemanusiaan STIBA Makassar di wilayah terdampak bencana telah diterapkan di beberapa daerah di Indonesia, di antaranya:

1. PkM yang dilakukan oleh mahasiswa Universitas Mataram di wilayah Lombok pasca bencana dengan mengusung program psikososial sebagai bentuk trauma healing untuk anak-anak yang terdampak gempa di Dusun Tanjung. Tujuan program ini untuk membantu pemulihan mental anak-anak dan mengobati trauma pasca gempa, program ini memberikan efek yang positif dalam menstabilkan kondisi psikologis anak-anak ${ }^{3}$.

2. PkM oleh mahasiswa Sekolah Tinggi Teknologi Garut dalam bentuk program relawan desa melawan wabah Covid-19 di Desa Mekarjaya Garut. Tujuan program ini memberikan edukasi kepada masyarakat terkait pentingnya pencegahan penularan wabah dengan menerapkan protokol kesehatan secara

${ }^{3}$ Humaira, Isnaini, and Ilham, "Psikososial Sebagai Bentuk Trauma Healing Untuk AnakAnak Terdampak Gempa," SINERGI:Jurnal Pengabdian Universitas Muhammadiah Mataram 1, no. 1 (2018): 12-16. 
disiplin. Hasil pembahasan menunjukkan adanya peningkatan kesadaran masyarakat untuk menerapkan protokol kesehatan dalam aktivitas mereka ${ }^{4}$.

3. PkM yang dilaksanakan oleh mahasiswa KKN Universitas Bangka Belitung dengan menjadi relawan Covid-19 di Kelurahan Bukit Betung. Pengabdian ini bertujuan untuk mengedukasi masyarakat akan pencegahan penyebaran virus Covid-19, serta memberikan konseling yang dibutuhkan dalam upaya pengembangan potensi masyarakat. Program ini berjalan lancar dan sukses dengan beberapa program seperti pembuatan desinfektan dan hand sanitizer, sosialisasi cara mencuci tangan yang benar serta pembagian masker dan hand sanitizer secara gratis ${ }^{5}$.

4. PkM yang bertajuk, "Sosialisasi Tanggap Bencana Melalui Pendekatan Literasi di Labuhan Haji Kabupaten Lombok Timur." Program KKN ini bertujuan untuk memberikan informasi penanganan bencana dengan menggunakan media cetak maupun online, dan tata laksana dalam mengantisipasi bahaya bencana untuk mengurangi risiko kerugian moril dan materiel. Program ini berhasil membentuk kelompok peduli bencana, relawan bencana dan tersedianya peta resiko bencana di setiap lingkungan ${ }^{6}$.

Beberapa PkM yang telah dipaparkan di atas, sejatinya menunjukkan bahwa pengabdian KKN kemanusiaan telah dilaksanakan sebelumnya dengan beragam program. Namun, yang menjadi perbedaan pada KKN kemanusiaan mahasiswi STIBA Makassar angkatan IV ini adalah program kegiatan yang lebih terfokus pada kegiatan dakwah dan sosial seperti pengajaran Al-Qur'an dan pembinaan keislaman melalui taklim dan semisalnya.

\section{PEMBAHASAN}

\section{Pelaksanaan Program KKN Kemanusiaan}

Kelurahan Malunda merupakan daerah yang terdampak cukup parah dan sempat terisolir beberapa waktu karena akses jalan yang terputus akibat gempa. Hal tersebut tentu memberikan dampak psikologis bagi masyarakat sehingga kehadiran mahasiswi KKN STIBA Makassar diharapkan dapat memfasilitasi keinginan masyarakat untuk mendapatkan pembinaan keislaman dengan lebih intensif. Sebelum kedatangan para mahasiswi KKN, terlihat tim tanggap bencana Wahdah telah lebih dahulu membantu masyarakat terdampak bencana dengan melakukan

${ }^{4}$ Yeni Pariyatin et al., "Meningkatkan Kesadaran Masyarakat Terhadap Protokol Kesehatan Melalui Program Relawan Desa Lawan Covid-19," Jurnal Pengabdian Masyarakat MIFTEK 1, no. 2 (2020): 166-175.

${ }^{5}$ Sindy Ayu Kirana and Refy Safitri, "Pengabdian KKN Kelurahan Bukit Betung Menjadi Relawan COVID-19 Di Wilayah Bangka Belitung," Prosiding Seminar Hukum Dan Publikasi Nasional (Serumpun) II 2 (2020): 461-470.

${ }^{6}$ Amin Saleh et al., "Sosialisasi Tanggap Bencana Pada Masyarakat Melalui Pendekatan Literasi Media Di Labuhan Haji Kabupaten Lombok Timur” 2, no. 2 (2019): 55-60. 
pelayanan kesehatan (medis), evakuasi korban, pengadaan dapur umum, pembenahan rumah-rumah warga yang rusak dan pembangunan tenda-tenda pengungsian. Sehubungan dengan kondisi riil tersebut, maka bentuk-bentuk kegiatan yang dilakukan mahasiswi KKN STIBA Makassar di Kelurahan Malunda berupa:

\section{Bakti Sosial}

Bencana yang menimpa wilayah Sulawesi Barat menyebabkan terhambatnya perekonomian bahkan sebagian wilayah mati total, tidak terkecuali di wilayah Kelurahan Malunda. Tampak di sana-sini masyarakat mengalami kesulitan dalam mendapatkan bahan pangan, dan mereka hanya bergantung pada bantuan relawan untuk proses distribusinya. Oleh karena itu, mahasiswi KKN bekerjasama dengan Muslimah Wahdah Peduli Majene serta Wahdah Inspirasi Zakat (WIZ) Majene merespon masalah ini dengan mengadakan program bakti sosial berupa pembagian Al-Qur'an dan sembako kepada masyarakat. Program ini termasuk program utama mahasiswi KKN Kemanusiaan Sulawesi Barat terkhusus di Kelurahan Malunda. Kegiatan ini diawali dengan melakukan pendataan dengan melakukan silaturahmi ke rumah-rumah masyarakat yang terdampak gempa yang ada di Kelurahan Malunda. Hal ini juga berguna dalam mendata masyarakat yang membutuhkan bantuan sembako.

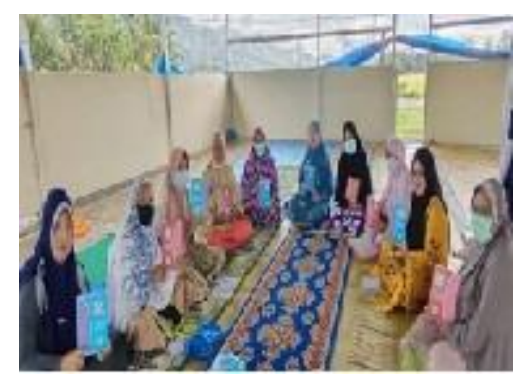

\section{Gambar 1. Bakti Sosial dan Tebar Al-Qur'an}

Berdasarkan data yang telah dihimpun, maka mahasiswi kemudian berkoordinasi dengan Muslimah Wahdah Peduli dan WIZ Majene untuk penyaluran bantuan, kegiatan bakti sosial ini juga menjadi sarana mahasiswi untuk menyosialisasikan beberapa agenda KKN yang lain seperti program belajar AlQur'an DIROSA, taklim muslimah dan lain-lain. Kegiatan ini berjalan lancar dan dilaksanakan satu kali untuk pembagian sembako. Adapun pembagian Al-Qur'an rutin dilaksanakan sekali sepekan. Dengan demikian, dampak daripada kegiatan ini terlihat sangat positif dan sangat diapresisasi oleh masyarakat sekitar, serta terbangun silaturahmi yang baik antar masyarakat dan mahasiswi KKN. 


\section{Pengajaran Al-Qur'an untuk Remaja dan Orang Dewasa}

Pengajaran Al-Qur'an ini menggunakan metode DIROSA yang menyasar kalangan dewasa dan remaja, baik yang kondisinya belum mengenal huruf hijaiah ataupun yang ingin memperbaiki kualitas bacaan Al-Qur'an, kegiatan diawali dengan sosialisasi kepada masyarakat khususnya ibu-ibu dan remaja putri kemudian pengelompokan peserta berdasarkan tingkat kemampuan baca AlQur'an.

Kegiatan belajar Al-Qur'an dengan metode DIROSA ini berjalan dengan lancer. Tampak perubahan di mana masyarakat yang dulunya masih terbata-bata dalam membaca, kini sudah memperoleh perubahan bacaan yang cukup baik. Mulai dari penyebutan makhraj huruf, tajwid dan lain-lain juga mulai dipahaminya. Semisal dengannya, Iskandar dan Amirullah menyatakan bahwa program Dirosah Qur'aniyah mampu memberikan pengaruh yang positif dalam menumbuhkan kecintaan warga Desa Tukamasea terhadap Al Qur'an?

Kendala yang dihadapi mahasiswi adalah untuk desa yang terpencil hanya bisa didatangi sekali sepekan, sehingga kelanjutan belajar mereka diambil alih oleh Muslimah Wahdah Majene. Adapun setelah usainya program ini, maka mahasiswi KKN STIBA Makassar mengadakan tindak lanjut kegiatan dengan membentuk kelompok Tahsin al-Qira'ah (perbaikan bacaan Al-Qur'an), dan program DIROSA akan tetap dilanjutkan oleh Muslimah Wahdah Peduli hingga masa tanggap bencana selesai.

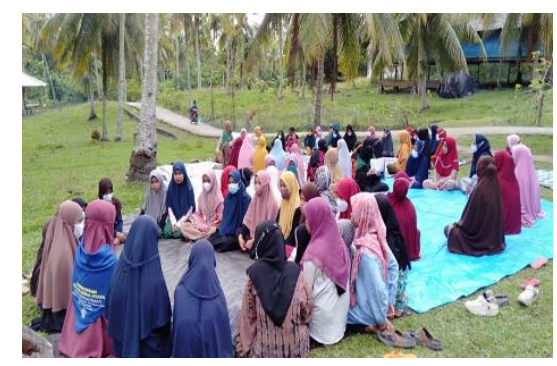

\section{Gambar 2. Pengajaran Al-Qur'an Metode Dirosa}

\section{Taklim Fikih Muslimah}

Taklim muslimah adalah kegiatan yang dirancang dalam bentuk penyampaian ceramah keislaman kepada ibu-ibu dan remaja putri di beberapa titik di Kelurahan Malunda dan beberapa titik di luar Kelurahan Malunda, seperti Desa Takapa dan Ulumanda bahkan hingga ke pelosok Kabupaten Majene. Pada dasarnya Sri dan Aswar menyebutkan bahwa tujuan dari kegiatan taklim muslimah

${ }^{7}$ Iskandar, Iskandar, and Muhammad Amirullah. "Pelaksanaan Dirasah Qur'aniyah sebagai Upaya Peningkatan Kualitas Baca Al-Qur'an di Desa Tukamasea Kabupaten Maros." WAHATUL MUJTAMA': Jurnal Pengabdian Masyarakat 1.1 (2020): 42-53. 
adalah penyampaian materi dan siraman kalbu, menambah wawasan keislaman, serta meningkatkan iman dan takwa masyarakat, khususnya muslimah ${ }^{8}$.

Strategi yang digunakan oleh para mahasiswi adalah dengan menyampaikan materi seputar dasar-dasar keislaman secara tematik di satu tempat, baik itu masjid ataupun rumah warga. Kemudian mahasiswi dibagi ke dalam beberapa tim sesuai lokasi atau desa dan menjadi pemateri tetap secara bergiliran.

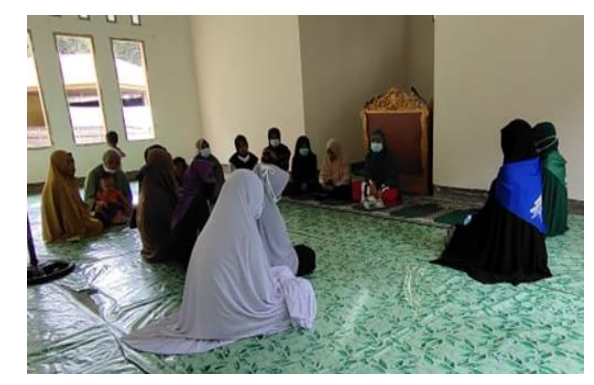

\section{Gambar 3. Kegiatan taklim muslimah}

Faktor pendukung dalam kegiatan ini adalah antusias ibu-ibu ketika menyimak materi, dan di sesi akhir kegiatan taklim dilanjutkan dengan silaturahmi dan sharing dengan para peserta taklim. Namun, terdapat kendala yang dihadapi oleh mahasiswi yaitu beberapa titik terkadang tidak terjangkau diakibatkan minimnya sarana transportasi dan medan yang cukup sulit serta terkadang terhalang oleh kondisi cuaca berupa hujan deras. Kondisi masyarakat pun mengalami perubahan yang bermakna, di mana sebelum adanya program ini, mereka mengalami keterbatasan dan kesulitan dalam belajar ilmu agama dikarenakan kurangnya dai dan daiyah. Masyarakat jarang mendengarkan ceramah subuh yang membahas seputar keislaman. Dengan adanya pelaksanaan program ini, tampak terjadi peningkatan yang cukup menggembirakan, di mana antusias dan motivasi masyarakat dalam mempelajari dasar-dasar keislaman atau fikih muslimah.

\section{Program Menghafal Al-Qur'an}

Program ini menyasar para remaja putri yang ada di Desa Lombang. Kegiatan ini pula dilaksanakan setiap hari setelah salat subuh, dan dimulai dengan berkumpul di posko KKN kemudian diawali dengan materi singkat tentang keutamaan menghafalkan Al-Qur'an. Setelah itu dilanjutkan dengan mengulang hafalan atau muroja'ah bersama-sama lalu peserta meyetorkan hafalan pada mahasiswi yang ditunjuk sebagai pengampu hafalan atau disebut muhaffidzah. Seyatinya, kegiatan ini tampak mendapat respon yang sangat baik dari para peserta

${ }^{8}$ Putri, Sri Ujiana, and Aswar Aswar. "Implementasi Pendidikan Masyarakat Berbasis Masjid untuk Muslimah di Desa Mattoanging Kabupaten Maros." WAHATUL MUJTAMA': Jurnal Pengabdian Masyarakat 1.2 (2020): 129-141. 
remaja, di mana mereka tetap bersemangat untuk selalu hadir di waktu subuh setiap hari, juga terlihat dari adanya penambahan hafalan dari para peserta.

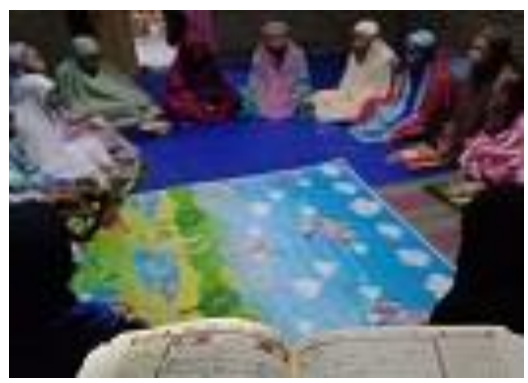

\section{Gambar 4. Kegiatan Menghafal Al-Qur'an}

\section{Festival Anak Saleh Desa Lombang}

Festival Desa Lombang merupakan kegiatan akbar tim KKN Kemanusiaan STIBA Makassar untuk mengevaluasi kegiatan yang telah dilakukan selama sebulan serta untuk mengasah potensi dan bakat masyarakat baik di bidang agama maupun olahraga.

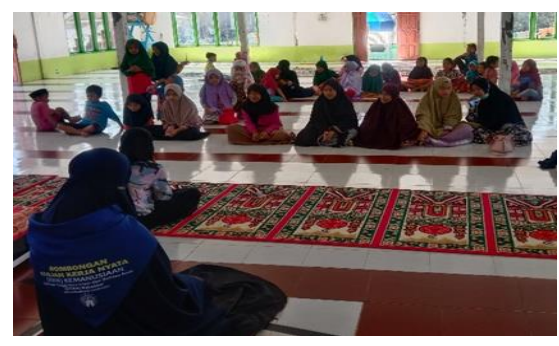

\section{Gambar 5. Festival Anak Saleh Desa Lombang}

Kegiatan ini dilakukan selama 5 hari dengan berbagai agenda lomba seperti lomba azan, lomba hafalan surah pendek, lomba tilawah dan lomba olah raga. Kegiatan akbar ini diikuti dengan antusias para peserta dan dukungan pemerintah setempat. Sehubungan dengannya, manfaat dari diadakannya Festival Anak Saleh tidak lain ialah untuk meningkatkan kompetensi dari sisi pengetahuan dasar keislaman, perilaku ibadah, adab, dan akhlak keseharian anak ${ }^{9}$.

\section{KESIMPULAN}

KKN kemanusiaan STIBA Makassar di wilayah Sulawesi Barat khususnya Kelurahan Malunda telah memberikan sedikit kontribusi dalam membantu pemerintah mengatasi permasalahan yang timbul pasca bencana berupa

${ }^{9}$ Aswar, A., \& Rosmita, R. (2020). Festival Anak Saleh di Desa Leang-leang Kabupaten Maros. WAHATUL MUJTAMA': Jurnal Pengabdian Masyarakat, 1(1), 54-66. 
penanganan aspek spiritual para korban bencana sebagai salah satu bentuk trauma healing pasca bencana.

Kegiatan ini juga mampu mengasah dan meningkatkan kepekaan sosial serta dakwah para mahasiswa sebagaimana hal tersebut terlihat dari kesungguhan dan komitmen mereka dalam memberikan pengabdian kepada masyarakat ditengah keterbatasan kondisi di tempat KKN. Pembinaan keagamaan dan pengajaran AlQur'an yang dilakukan para mahasiswi relawan di lokasi bencana memberikan efek yang cukup positif bagi masyarakat dalam menangani tekanan psikologis pasca gempa, serta memberikan kontribusi yang signifikan bagi kualitas personil relawan dalam membantu masyarakat yang terdampak bencana di Kelurahan Malunda.

\section{DAFTAR PUSTAKA}

Aswar, Aswar, and Rosmita Rosmita. "Festival Anak Saleh di Desa Leang-leang Kabupaten Maros." WAHATUL MUJTAMA': Jurnal Pengabdian Masyarakat 1.1 (2020): 54-66.

Humaira, Isnaini, and Ilham. "Psikososial Sebagai Bentuk Trauma Healing Untuk Anak-Anak Terdampak Gempa.” SINERGI:Jurnal Pengabdian Universitas Muhammadiah Mataram 1, no. 1 (2018): 12-16.

Iskandar, Iskandar, and Muhammad Amirullah. "Pelaksanaan Dirasah Qur'aniyah sebagai Upaya Peningkatan Kualitas Baca Al-Qur'an di Desa Tukamasea Kabupaten Maros." WAHATUL MUJTAMA': Jurnal Pengabdian Masyarakat 1.1 (2020): 42-53.

Kirana, Sindy Ayu, and Refy Safitri. "Pengabdian KKN Kelurahan Bukit Betung Menjadi Relawan COVID-19 Di Wilayah Bangka Belitung." Prosiding Seminar Hukum Dan Publikasi Nasional (Serumpun) II 2 (2020): 461-70.

Pariyatin, Yeni, Hilda Lestari, Widianti Sri Anjani, Anggi Ahmad Mulyadi, Aldi Yuliandi, and Danil Ardiansyah. "Meningkatkan Kesadaran Masyarakat Terhadap Protokol Kesehatan Melalui Program Relawan Desa Lawan Covid-19." Jurnal Pengabdian Masyarakat MIFTEK 1, no. 2 (2020): 16675.

Putri, Sri Ujiana, and Aswar Aswar. "Implementasi Pendidikan Masyarakat Berbasis Masjid untuk Muslimah di Desa Mattoanging Kabupaten Maros." WAHATUL MUJTAMA': Jurnal Pengabdian Masyarakat 1.2 (2020): 129141.

Saleh, Amin, Iwin Ardyawin, Muh Rizqan R, and Intan Kurniani. "Sosialisasi Tanggap Bencana Pada Masyarakat Melalui Pendekatan Literasi Media Di Labuhan Haji Kabupaten Lombok Timur" 2, no. 2 (2019): 55-60.

Setiawan, Heri, et al. "Pendampingan Trauma Pascagempa Berbasis Kearifan Lokal di Desa Kayangan Kabupaten Lombok Utara." Jurnal Abdimas PHB: Jurnal Pengabdian Masyarakat Progresif Humanis Brainstorming 4.1 (2021): 115122. 